Metallophysics and Advanced Technologies

Металофіз. новітні технол.

Metallofiz. Noveishie Tekhnol.

2021 , vol. 43 , No. 3 , pp. 399-406

https://doi.org/10.15407/mfint.43.03.0399

Reprints available directly from the publisher
(C) 2021 G. V. Kurdyumov Institute for Metal Physics, National Academy of Sciences of Ukraine Published by license under

the G. V. Kurdyumov Institute for Metal PhysicsN.A.S. of Ukraine Publishers imprint. Printed in Ukraine.

PACS numbers: 61.80.Ba, 62.20.Qp, 64.60.My, 81.20.Vj, 81.40.Gh

\title{
Structure of High-Entropy AlCoCrFeNi Alloy Obtained by Laser Alloying
}

\author{
V. V. Girzhon, V. V. Yemelianchenko, and O. V. Smolyakov \\ Zaporizhzhya National University, \\ 66 Zhukovsky Str., \\ UA-69600 Zaporizhzhya, Ukraine
}

The structural-phase state of the AlCoCrFeNi high-entropy alloy obtained by laser alloying of technically pure aluminium surface layers with a mixture of powders of pure elements $\mathrm{Fe}, \mathrm{Co}, \mathrm{Ni}, \mathrm{Cr}$ in an equiatomic ratio is investigated by X-ray phase, X-ray spectral, and metallographic analyses. As shown, in the process of laser alloying the formation of a heterophase structure, which consists of an ordered multicomponent substitution solid solution based on b.c.c. lattice and $\mathrm{Al}_{13}(\mathrm{Me})_{4}$ monoclinic intermetallide, take place. As established, the formation of such a structure is a consequence of melt high cooling rates, high aluminium content and inhomogeneous distribution of chemical components in the surface and bottom layers of the laser alloying zone. The microhardness of the alloyed surface is $4.7 \mathrm{GPa}$, which is typical for high-entropy alloys of this system obtained by other methods. Additional reasons that may affect the high values of microhardness are analysed.

Key words: high-entropy alloy, laser alloying zone, chemical inhomogeneity, substitution solid solution, high cooling rates, phase composition.

Методами рентґенівського фазового, рентґеноспектрального та металографічного аналізів досліджено структурно-фазовий стан високоентропійного стопу системи $\mathrm{AlCoCrFeNi,} \mathrm{одержаного} \mathrm{за} \mathrm{допомогою} \mathrm{лазерного} \mathrm{легу-}$ вання поверхневих шарів технічно чистого алюмінію А8 сумішшю порошків чистих елементів $\mathrm{Fe}, \mathrm{Co}, \mathrm{Ni}, \mathrm{Cr}$ у еквіатомному співвідношенні. Показано, що в процесі лазерного легування відбувалося формування гетерофазної структури, що складалася з впорядкованого багатокомпонентного твердого розчину заміщення на основі ОЦК-гратки та моноклінного інте-

Corresponding author: Vladyslav Vasyl'ovych Yemelianchenko

E-mail: emelyanchenkovlad@gmail.com

Citation: V. V. Girzhon, V. V. Yemelianchenko, and O. V. Smolyakov, Structure of High-Entropy AlCoCrFeNi Alloy Obtained by Laser Alloying, Metallofiz. Noveishie Tekhnol., 43, No. 3: 399-406 (2021), DOI: 10.15407/mfint.43.03.0399. 
рметаліду $\mathrm{Al}_{13}(\mathrm{Me})_{4}$. Встановлено, що формування такої структури є наслідком високих швидкостей охолодження розтопу, високого вмісту алюмінію та неоднорідного розподілу хімічних компонентів у поверхневих та придонних шарах зони лазерного легування. Мікротвердість легованої поверхні складала 4,7 ГПа, що є характерним для високоентропійних стопів даної системи одержаних іншими методами. Проаналізовано додаткові причини, які можуть впливати на високі значення мікротвердості.

Ключові слова: високоентропійний стоп, зона лазерного легування, хімічна неоднорідність, твердий розчин заміщення, високі швидкості охолодження, фазовий склад.

(Received September 7, 2020; in final version, December 22, 2020)

\section{INTRODUCTION}

High-entropy alloys (HEAs) are a relatively new class of materials, with their inherent complex of original physical and mechanical properties. A distinctive feature of such alloys is increased, compared to traditional, values of mixing entropy, which are usually about $13-19 \mathrm{~J} /(\mathrm{mol} \cdot \mathrm{K})$. Such values of mixing entropy lead to the minimization of free energy, as a result, instead of intermetallic compounds formation, the formation of multicomponent substitution solid solutions with b.c.c., f.c.c. or h.c.p. lattices can occur [1]. Crystal lattice distortion and internal stresses cause low, compared to traditional alloys, diffusion coefficients values of HEAs. The result is their high thermal stability [2].

A significant part of the studied HEAs was obtained by vacuum-arc melting or melting in an argon atmosphere [3]. However, today in the industry the use of HEAs as, for example, protective coatings, films, diffusion barriers with high physical and chemical properties is promising [4].

One of the effective ways to obtain these coatings is laser alloying (LA). The high cooling rates of the melt $\left(10^{3}-10^{6} \mathrm{~K} / \mathrm{s}\right)$, typical for this method, help to reduce components segregation and prevent the formation and growth of brittle intermetallic compounds [5, 6]. The structure of HEAs obtained by this method is usually represented by columnar and equiaxed grains [7]. It should be mentioned that the question of the influence of kinetic factors on the structural formation processes of high-entropy coatings (particularly in laser alloying process) is not fully covered, as the number of publications in this field is small. Therefore, the aim of this study is to analyse the structural-phase state of AlCoCrFeNi high-entropy alloy obtained by laser alloying.

\section{EXPERIMENTAL/THEORETICAL DETAILS}

The material for alloying (matrix) were samples of technically pure al- 
uminium, the chemical composition of which is presented in Table 1. This alloy is similar in composition to alloys Aluminium 1080, Aluminium 1080A (USA) and ENAW-1080A (EU).

Alloying was performed on a pulsed YAG laser $(\lambda=1.06 \mu \mathrm{m})$ at power density of $990 \mathrm{MW} / \mathrm{m}^{2}$ and a pulse frequency $v=2 \mathrm{~Hz}$. The alloying components were a mixture of powders of pure elements $\mathrm{Fe}, \mathrm{Co}, \mathrm{Ni}, \mathrm{Cr}$ in an equiatomic ratio (the size of the fractions did not exceed $50 \mu \mathrm{m}$ ). BF-6 glue was chosen as the binder. The thickness of the coating was $150 \mu \mathrm{m}$. The alloying was carried out in an argon protective atmosphere. The phase composition of the samples surface layers in the initial state and after laser alloying was determined by X-ray diffraction (radiation $\mathrm{Cu} K_{\alpha}$ ), X-ray spectroscopy and metallographic analyses.

\section{RESULTS AND DISCUSSION}

X-ray analysis of the samples in the initial state showed that they were in a single-phase polycrystalline state with a chaotic orientation of the grains.

On the X-ray diffraction curves from the alloyed surface were reflections from the lattice of three phases: multicomponent solid solution based on b.c.c. lattice, intermetallic $\mathrm{Al}_{13}(\mathrm{Me})_{4}(\mathrm{Me}$-alloying components) with $\mathrm{Al}_{13} \mathrm{Fe}_{4}$ structural type [9], and low-intensity reflections from aluminium lattice (Fig. 1, $a$ ). There were no features on the diffraction pattern that would indicate the presence of carbon due to the use of organic binders.

Analysis of binary state diagrams of the $\mathrm{Al}-\mathrm{Me}[10]$ showed that intermetallic $\mathrm{Al}_{13}(\mathrm{Me})_{4}$ can be formed only in the $\mathrm{Al}-\mathrm{Fe}$ and $\mathrm{Al}-\mathrm{Co}$ systems. From the consideration of triple diagrams $\mathrm{Al}-\mathrm{Fe}-\mathrm{Co}$ [11], $\mathrm{Al}-$ $\mathrm{Fe}-\mathrm{Cr}$ [12], $\mathrm{Al}-\mathrm{Fe}-\mathrm{Ni}$ [13], $\mathrm{Al}-\mathrm{Co}-\mathrm{Cr}$ [14], $\mathrm{Al}-\mathrm{Co}-\mathrm{Ni}$ [15] it can be concluded that the main alloying elements in the lattice of intermetallic $\mathrm{Al}_{13}(\mathrm{Me})_{4}$ is iron and cobalt, because the phase $\mathrm{Al}_{13}(\mathrm{Fe}, \mathrm{Co})_{4}$ within the range of its homogeneity in the system $\mathrm{Al}-\mathrm{Fe}-\mathrm{Co}$ is characterized by a continuous series of solid solutions-from $\mathrm{Al}_{13} \mathrm{Fe}_{4}$ to $\mathrm{Al}_{13} \mathrm{Co} 4$. The solubility of chromium and nickel in this type of lattice is lower.

It should be noted that the formation of an $\mathrm{Al}_{13}(\mathrm{Me})_{4}$ type monoclinic phase is typical for the phase formation processes at high cooling rates

TABLE 1. Chemical composition of technical aluminium, at.\% [8].

\begin{tabular}{c|c|c|c|c|c|c|c|c|c}
\hline \multirow{2}{*}{$\begin{array}{c}\mathrm{Al}, \\
\text { min }\end{array}$} & \multicolumn{7}{c}{ Impurities (no more than) } \\
\cline { 2 - 10 } & $\mathrm{Si}$ & $\mathrm{Mn}$ & $\mathrm{Ti}$ & $\mathrm{Cu}$ & $\mathrm{Mg}$ & $\mathrm{Zn}$ & $\mathrm{Ga}$ & $\begin{array}{c}\text { Other im- } \\
\text { purities, } \\
\text { each }\end{array}$ \\
\hline 99.8 & 0.12 & 0.1 & 0.02 & 0.01 & 0.02 & 0.02 & 0.04 & 0.03 & 0.02 \\
\hline
\end{tabular}


of the melt in the above-mentioned systems. In addition, it is interesting that this type of phases can be approximants to quasicrystalline phases. Thus, according to [16], the $\mathrm{Al}_{13}\left(\mathrm{Co}_{1-y} \mathrm{Ni}_{y}\right)_{4}$ phase is an approximant to the decagonal phase $\mathrm{Al}_{70} \mathrm{Co}_{15} \mathrm{Ni}_{15}$.

It is known [17] that at a high aluminium content in the $\mathrm{Al}-\mathrm{Co}-\mathrm{Cr}-$ $\mathrm{Fe}-\mathrm{Ni}$ system, two b.c.c. solid solutions are formed-disordered and ordered. The presence of diffraction maxima like (100) and (111), forbidden for b.c.c., testified to the ordered solid solution presence. The ordered phase based on the b.c.c. lattice is isostructural to the lattice of binary compounds $\mathrm{CsCl}, \mathrm{CuZn}, \mathrm{AlNi}$, etc., which are indicated on the state diagrams in $\mathrm{Al}-\mathrm{Me}$ systems as $B 2$ phase [10]. In this case, accord-

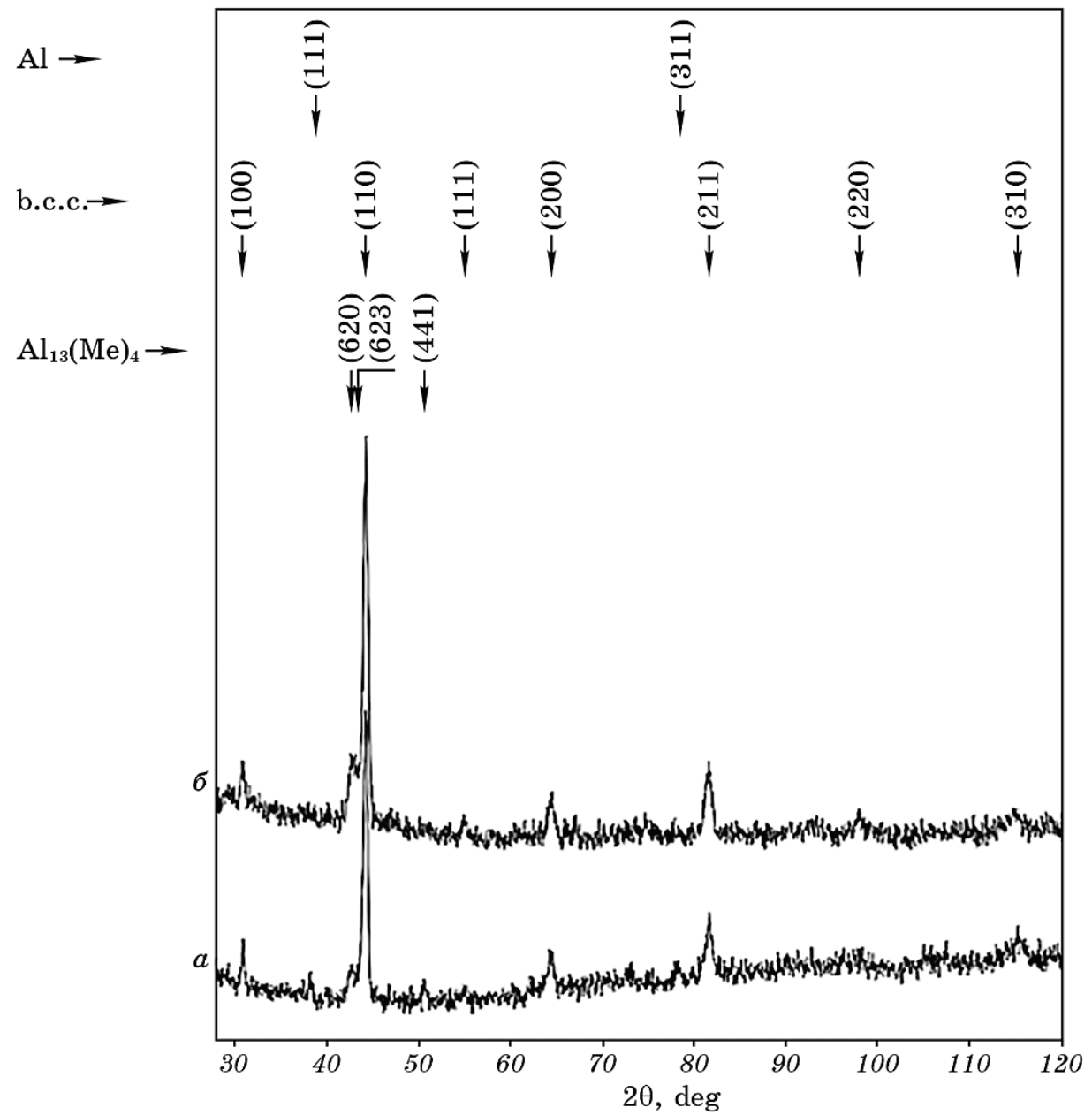

Fig. 1. X-ray diffraction curves from the surface layers of the samples after laser alloying $(a)$ and additional laser alloying $(b)$. 
ing to [1], the basis of such a lattice is diatomic, where aluminium atoms mainly occupy sites with coordinates [000], and alloying components atoms are statistically distributed in sites with coordinates $\left[\begin{array}{lll}1 / 2 & 1 / 2 & 1 / 2\end{array}\right]$.

The presence of reflections from the pure aluminium lattice and intermetallic $\mathrm{Al}_{13}(\mathrm{Me})_{4}$ on the diffraction patterns (Fig. 1, $a$ ) indicated an excess of aluminium in the laser alloying zone (LAZ). Therefore, in order to reduce the amount of aluminium in the LAZ, the surface was additionally alloyed with parameters analogous to the initial one. After such treatment, only two phases were present in the surface layers structure of the samples: the ordered b.c.c. phase and the $\mathrm{Al}_{13}(\mathrm{Me})_{4}$ phase (Fig. 1, $b$ ). The simultaneous presence on the diffraction patterns lattice reflections of the ordered b.c.c. solid solution and the intermetallic $\mathrm{Al}_{13}(\mathrm{Me})_{4}$ may be caused by the chemical inhomogeneity of the component's distribution in the LAZ.

After each alloying, the lattice parameter of the b.c.c. phase was precisely determined: after the initial alloying it was equal to $a=$ $=0.28832 \pm 0.00006 \mathrm{~nm}$, after the additional alloying $-a=0.28801 \pm$ $\pm 0.00006 \mathrm{~nm}$. It should be indicated, that the obtained value of the solid solution lattice parameter after the initial alloying practically coincided with the lattice parameter of this phase obtained in [18]. The decrease in the lattice parameter after additional alloying can be explained by the fact that such treatment led to an increase in the alloying components content in LAZ, and, consequently, to a decrease in aluminium content, the atomic radius of which exceeded the atomic radii of alloying components.

The surface of the samples after laser alloying was characterized by the presence of microrelief. Therefore, for electron microscopic studies of the surface, it was polished until the disappearance of roughness. The picture of the sample surface in the reflected electrons after polishing is shown in Fig. 2. The presence of a number of cracks on the surface could be due to the hardening stresses that occurred in the LAZ during rapid cooling of the melt, and the fragility of the BCC phase.

Table 2 shows the average results of X-ray spectral analysis of the alloyed surface after removal of the microrelief. As it can be seen from the table, the surface layers were characterized by a high content of aluminium, which does not contradict with phase composition of the superficial layers of LAZ obtained by XRD phase analysis.

The deviation of the alloying components distribution in the surface layers from the equiatomic composition can be explained by the uneven distribution of alloying components by LAZ depending on depth. Therefore, at the next stage of the research, further surface polishing was carried out in order to establish the chemical composition of LAZ bottom areas. Distribution of chemical components in the bottom areas of LAZ are presented in Fig. 3. 
TABLE 2. The content of alloying components in LAZ, at. $\%$.

\begin{tabular}{c|c|c|c|c}
\hline $\mathrm{Al}$ & $\mathrm{Co}$ & $\mathrm{Cr}$ & $\mathrm{Fe}$ & $\mathrm{Ni}$ \\
\hline 59.3 & 8.2 & 14.2 & 8.5 & 9.8 \\
\hline
\end{tabular}

Significant chemical inhomogeneity in the bottom areas can be explained by the fact that the processes of structure formation during laser alloying were influenced mainly by two factors: the MarangoniGibbs capillary effect [19] and the change in the cooling rate according to the depth of LAZ. Due to the Marangoni-Gibbs effect, there was macro-mixing of components in LAZ. The high cooling rates led to the crystallization process began before the uniform components distribution was achieved due to the capillary effect. The maximum cooling rate is in the bottom areas of LAZ, so they crystallized first. Therefore, the chemical inhomogeneity in these areas was higher than in the surface layers. As a result, the phase composition of the bottom sections could differ slightly from the phase composition of the surface layers.

The microhardness of the alloyed surface was $4.7 \mathrm{GPa}$. Similar values of microhardness are typical for HEAs [1,3], which further confirms the established presence of a multicomponent solid solution based on b.c.c. lattice, typical for high-entropy alloys, in the alloyed layers. It should be noted that the high dispersion degree of the structure can also be an additional reason of high microhardness values of

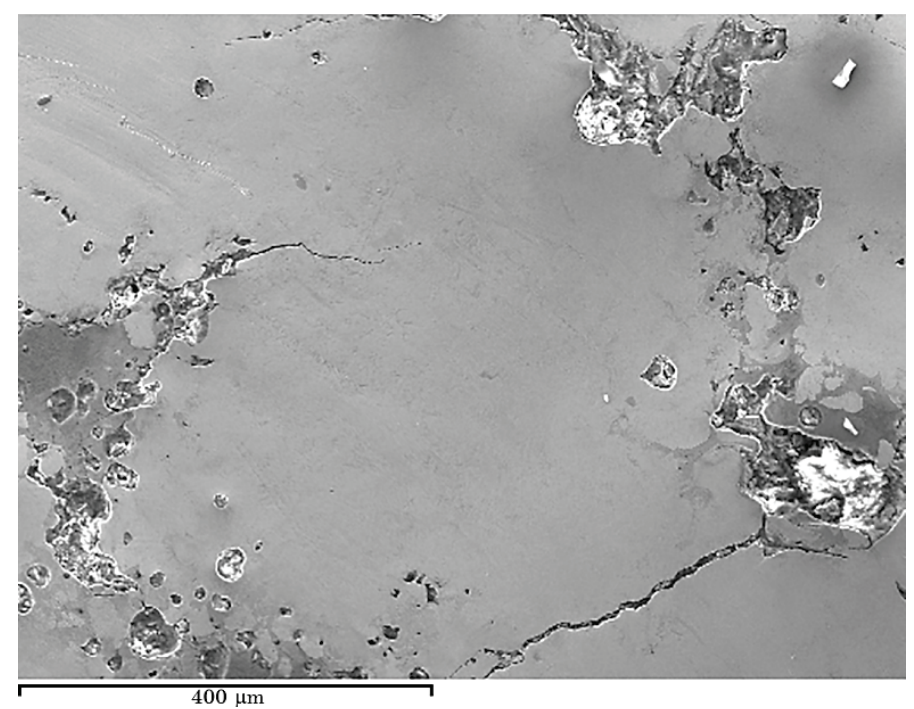

Fig. 2. The surface of the laser alloyed sample in the reflected electrons after polishing. 

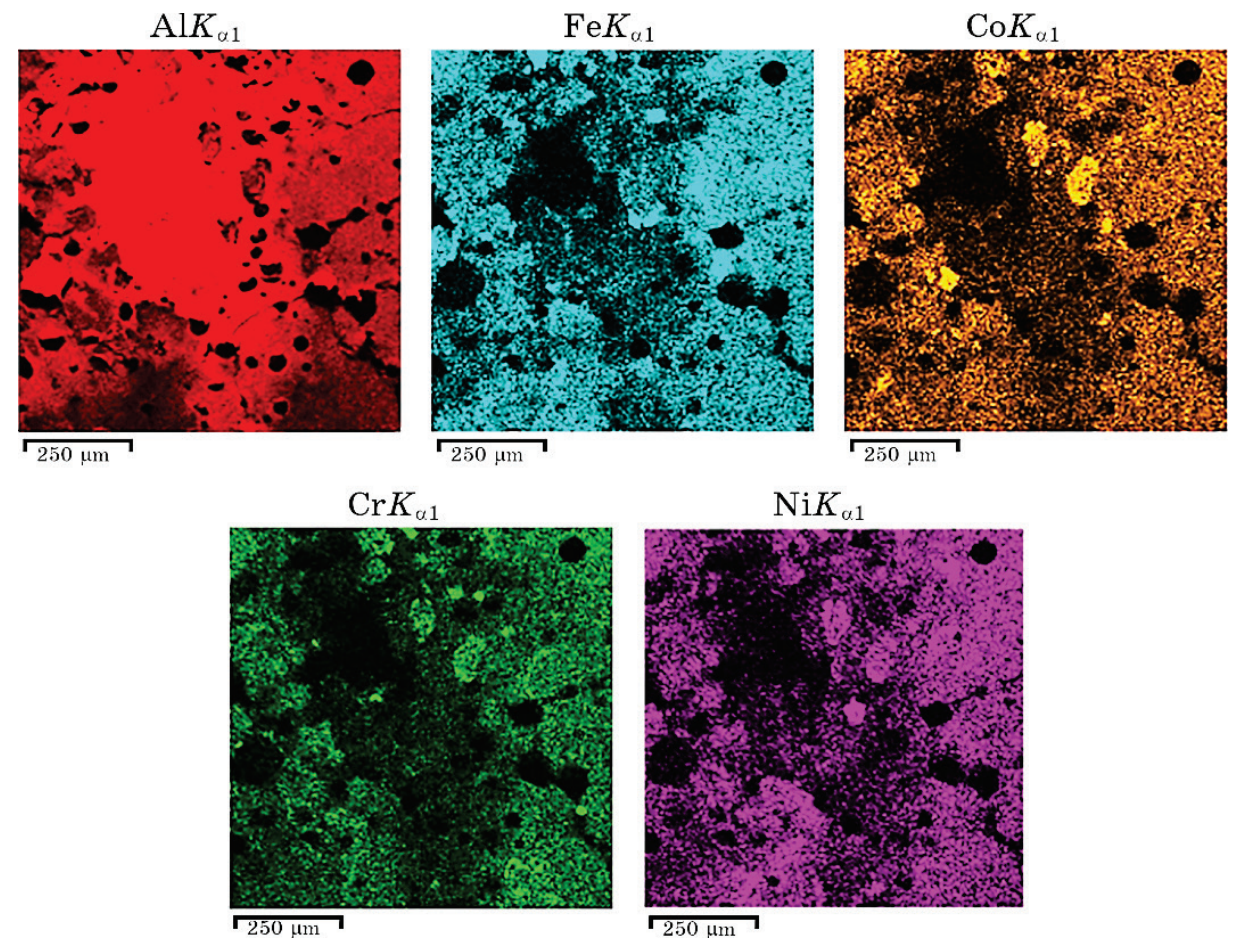

Fig. 3. Distribution of chemical components in the bottom areas of LAZ.

alloyed surface.

\section{CONCLUSION}

1. In the process of technically pure aluminium laser alloying with a mixture of pure elements $\mathrm{Fe}, \mathrm{Co}, \mathrm{Ni}, \mathrm{Cr}$ powders in the equiatomic ratio, a dispersed heterophase structure was formed, which included an ordered multicomponent substitution solid solution based on b.c.c. lattice and intermetallic $\mathrm{Al}_{13}(\mathrm{Me})_{4}$. The formation of such structure provided an increase in microhardness values of laser alloying area to 4.7 GPa.

2 . The inhomogeneous distribution of chemical components in the surface and bottom layers of LAZ was caused by the influence of two factors on the structure formation processes: the Marangoni-Gibbs effect and the cooling rate gradient of the melt depending on depth of LAZ.

\section{REFERENCES}

1. B. S. Murty, J. W. Yeh, and S. Ranganathan, High-Entropy Alloys (Butterworth Heinemann: 2014). 
2. C. Ng, S. Guo, J. Luan, S. Shi, and C. T. Liu, Intermetallics, 31: 165 (2012).

3. Y. Zhang, High-Entropy Materials: A Brief Introduction (Singapore: Springer: 2019).

4. X. H. Yan, J. S. Li, W. R. Zhang, and Y. Zhang, Mater. Chem. Phys., 210: 12 (2018).

5. H. Zhang, Y. Z. He, X. M. Yuan, and Y. Pan, Appl.Surf. Sci., 256, No. 20: 5837 (2010).

6. H. Assadi, S. Reutzel, and D. M. Herlach, Acta Mater., 54, No. 10: 2793 (2006).

7. H. Zhang, Y. Pan, Y. Z. He, J. L. Wu, T. M. Yue, and S. Guo, The Minerals, Metals Materials Society, 66, No. 10: 2057 (2014).

8. A. I. Belyaev, O. S. Bochvar, N. Ya. Buinov, N. I. Kolobnev, A. A. Kolpchev, L. L. Kostyukov, K. S. Lokhodaev, O. G. Senatorova, R. R. Romanova, E. A. Tkachenko, and I. N. Fridlyander, Metallovedenie Alyuminiya i Ego Splavov [Metallurgy of Aluminium and Its Alloys] (Moscow: Metallurgiya: 1987) (in Russian).

9. J. Grin, U. Burkhardt, M. Ellner, and K. Peters, Crystalline Materials, 209, No. 6: 479 (1994).

10. Binary Alloy Phase Diagrams (Eds. H. Okamoto, M. E. Schlesinger, and E. M. Mueller) (ASM International: 2016).

11. V. Raghavan, J.Phase Equilib. Diff., 29, No. 6: 515 (2008).

12. V. Raghavan, J. Phase Equilib. Diff., 33, No. 1: 55 (2012).

13. V. Raghavan, J.Phase Equilib. Diff., 29, No. 2: 180 (2008).

14. X. L. Liu, T. Gheno, B. B. Lindahl, G. Lindwall, B. Gleeson, and Z. K. Liu, PLoS ONE, 10, No. 4: 1 (2015).

15. V. Raghavan, J. Phase Equilib. Diff., 27, No. 4: 372 (2006).

16. P. Jeglič, S. Vrtnik, M. Bobnar, M. Klanjšek, B. Bauer, P. Gille, Yu. Grin, F. Haarmann, and J. Dolinšek, Phys. Rev. B, 82, No. 10: 104201 (2010).

17. Y. F. Kao, T. J. Chen, S. K. Chen, and J. W. Yeh, J.Alloy Compd., 488, No. 1: 57 (2009).

18. M. V. Karpets', O. M. Myslyvchenko, O. S. Makarenko, M. O. Krapivka, V. F. Horban', and A. V. Samelyuk, Problemy Tertya ta Znoshuvannya, 63, No. 2: 103 (2014) (in Ukrainian).

19. Lazernye Tekhnologii Obrabotki Materialov: Sovremennye Problemy Fundamental'nykh Issledovaniy i Prikladnykh Razrabotok [Laser Technology of Materials Processing: Modern Problems of Fundamental Research and Applied Development] (Ed. B. Ya. Panchenko) (Moscow: Fizmatlit: 2009). 